\title{
Hemidystonia-hemiatrophy syndrome
}

INSERM

\section{Source}

INSERM. (1999). Orphanet: an online rare disease and orphan drug data base.

Hemidystonia-hemiatrophy syndrome. ORPHA:306741

Hemidystonia-hemiatrophy (HD-HA) is a rare dystonia, usually caused by a static

cerebral injury occurring at birth or during infancy, that is characterized by a combination

of hemidystonia (HD), involving one half of the body, and hemiatrophy (HA) on the same side as the HD. 